\title{
Efficacy of jamun Syzygium cumini seed and orange Citrus sinensis peel extracts against microcystin LR induced histological damage in the kidney of rat
}

\section{Babita Deep Srivastava ${ }^{1}$, Manish Srivastava ${ }^{2}$, Makoto Urata $^{3,4}$, Nobuo Suzuki ${ }^{4}$ and Ajai Kumar Srivastav ${ }^{1, *}$}

\author{
${ }^{1}$ DDU Gorakhpur University. Department of Zoology. Gorakhpur 273009. India. \\ *Email: ajaiksrivastav@hotmail.com. \\ ${ }^{2}$ Digvijai Nath P.G. College. Department of Chemistry. Gorakhpur. India. \\ ${ }^{3}$ Institute of Noto SATOUMI Education Research. Noto-cho. Ishikawa 927-0553. \\ Japan. \\ ${ }^{4}$ Kanazawa University. Division of Marine Environmental Studies. Institute of \\ Nature and Environmental Technology. Noto Marine Laboratory. Noto-cho, \\ Ishikawa 927-0553, Japan.
}

\begin{abstract}
In this study we evaluated the protective effects of jamun Syzygium cumini seed and orange Citrus sinensis peel extracts on renotoxicity of microcystin LR in male rats. Groups A-F were given daily treatments for 30 days. Group A (Control): No treatment was given; Group B: microcystin $(10 \mu \mathrm{g} / \mathrm{kg}$ body wt); Group C: microcystin (10 $\mu \mathrm{g} / \mathrm{kg}$ body wt) and jamun seed extract $(200 \mathrm{mg} / \mathrm{kg}$ body $\mathrm{wt}) ;$ Group D: microcystin $(10 \mu \mathrm{g} / \mathrm{kg}$ body wt) and orange peel extract ( $200 \mathrm{mg} / \mathrm{kg}$ body wt; Group E: orange peel extract ( $200 \mathrm{mg} / \mathrm{kg}$ body wt); Group F: jamun seed extract $(200 \mathrm{mg} / \mathrm{kg}$ body $\mathrm{wt})$. Kidney were fixed at 15th and 30th day after the treatments. In 15 day MCLR (group B) treated rats shrunken glomeruli, hypertrophy of epithelial cells of tubules. vacuolation of cytoplasm and obliterated tubular lumina were noticed. In MCLR+JSE (group C) and MCLR+OPE (group D) treated rats almost similar changes were noticed as seen in MCLR treated rats. In OPE (group E) and JSE (group F) treated rats no visible morphological alterations were noticed. Following 30 day MCLR treatment (group B), increased cellularity of glomeruli, no space between the Bowman's capsule and glomerulus, glomerular degeneration, dilated tubules, separation of tubular epithelial cells from underlying basement membrane, tubular vacuolization and degeneration with necrotic nuclei in lumina and deposition of eosin-positive material in the tubules were observed. In MCLR+JSE (group C) and MCLR+OPE (group D) treated rats the glomeruli were swollen showing increased cellularity. No degeneration was noticed in glomeruli. Tubules were dilated, however, at few places few epithelial cells were degenerating. Necrotic nuclei
\end{abstract}

Received

May 25, 2020

Accepted

August 28, 2020

Released

December 31, 2020

Full Text Article

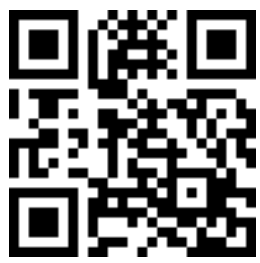

ORCID

(1) 0000-0002-9545-5360

Babita Deep

Srivastava

(1) 0000-0002-3718-2763

Manish Srivastava

D 0000-0001-9218-9987

Makoto Urata

(D) 0000-0003-0283-9910

Nobuo Suzuki 
were not seen in tubular lumina. In OPE (group E) and JSE (group F) treated rats the kidney exhibited no histological changes.

Keywords: Microcystin; Syzygium cumini; Citrus sinensis; Kidney; Cyanobacteria.
0000-0002-3873-0434

Ajai Kumar Srivastav

\section{Introduction}

In many parts of the world an increasing environmental hazard has been reported due to toxic cyanobacteria which are found in freshwater, eutrophic and municipal water supplies (Filipic et al., 2007). Cyanobacteria produce hepatotoxins, neurotoxins and lipopolysaccharide endotoxins (Srivastava and Srivastav, 2017). Ingestion of cyanobacteria adversely affects domestic and aquatic animals as well as humans (Elleman et al., 1978; Zin and Edwards, 1979; Bell and Codd, 1994; Negri et al., 1995; Benson et al., 2005; Shahi et al., 2012; Srivastava and Srivastav, 2017).

Microcystis aeruginosa is commonly observed in cyanobacterial blooms (Shahi et al., 2012) which produce a cyclic hepatotoxin-microcystin LR (Hooser et al., 1990; Carmichael, 1992; Watanabe et al., 1996; Benson et al., 2005; Kim et al., 2006; Srivastava and Srivastav, 2017). Few workers have reported accumulation of microcystin in bivalves (Prepas et al., 1997; Williams et al., 1997; Amorim and Vasconcelos, 1999), snails (Xie et al., 2005; Papadimitriou et al., 2012), shrimp (Xie et al., 2005; Zhang et al., 2009; Papadimitriou et al., 2012), frogs (Papadimitriou et al., 2012) and human liver (Greer et al., 2018). There are reports that microcystin LR produce hepatic damage in rats (Kim et al., 2006; Srivastava and Srivastav, 2017), however, there are evidences which suggest that it also affects kidney (Dias et al., 2009; Shahi et al., 2012; Xiping et al., 2019; Wang et al., 2019), heart (Shahi et al., 2012), germ cell apoptosis (Zhao et al., 2018) and human respiratory system (Brozman et al., 2020).

Black plum Syzygium cumini is found in Asian subcontinent, Eastern Africa, South America, Madagaskar, and some parts of United States of America (Swami et al., 2012; Srivastava and Srivastav, 2017). It is also known as java plum, Indian blackberry, jamun, jambolao, jambul etc. (Srivastava and Srivastav, 2017; Chagas et al., 2018). Various workers have attributed some biological activities to Syzygium cumini, namely cardioprotective, anti-inflammatory, hepatoprotective, antineoplastic, hypoglycemic, hypolipidemic, antibacterial and antiallergic (Giri et al., 1985; Raza et al., 2017; Srivastava and Srivastav, 2017; Chagas et al., 2018).

Orange Citrus sinensis peel is a rich source of flavonoids, carotenoids, limnoids, acridone alkaloids, vitamin C and B complex, essential oils and minerals (Calabro et al., 2004; Hegazy and Ibrahim, 2012; Madhuri et al., 2014; Muhtadi et al., 2015; Ashraf et al., 2017; Srivastava and Srivastav, 2017). Orange peels have been reported to possess antioxidant, antibacterial, larvicidal, antifungal activity (Gorinstein et al., 2001; Ghasemi et al., 2009; Ramful et al., 2010; Hegazy and Ibrahim, 2012; Parashar et al., 2014; Madhuri et al., 2014; Bashandy et al., 2019). It has been reported that flavonone and hespiridin present in Citrus are anti-inflmmatory and antihypertensive (Gil-Izquierdo et al., 2001; Bashandy et al., 2019). Muhtadi et al. (2015) have reported that Citrus sinensis peel extract possess antidiabetic and antihypercholesterolemic potential in rats.

The present study was aimed to evaluate the protective effects of extracts of jamun (Syzygium cumini) seeds and orange (Citrus sinensis) peels against microcystin LR (MCLR) induced histological changes in the kidney of male rats. Prior to this study no report exists regarding protective effects of extracts of seed of Syzygium cumini (JSE) and peels of Citrus sinensis (OPE) on renotoxicity induced by microcystin LR. 


\section{Materials and methods}

Male Wistar rats (70-90 g) were housed in polypropylene cages and acclimatized for 2 weeks under laboratory conditions prior to different treatments. During entire experimental period rats were maintained on the standard laboratory feed and water ad libitum. Animal handling and sacrifice were carried out following the guidelines provided by Ethics Committee of the University.

After acclimation rats were divided into six groups - A, B, C, D, E, and F, each consisting of 20 animals. Following treatments were orally given daily to these groups at 08:00 each day throughout the experiment:

Group A (Control): No treatment was given.

Group B (Microcystin-treated rats; MCLR): Received daily only microcystin (10 $\mu \mathrm{g} / \mathrm{kg}$ body wt).

Group C (Microcystin+jamun seed extract; MCLR+JSE): These rats were given daily microcystin $(10 \mu \mathrm{g} / \mathrm{kg}$ body $\mathrm{wt})$ and jamun seed extract $(200 \mathrm{mg} / \mathrm{kg}$ body $\mathrm{wt})$ simultaneously.

Group D (Microcystin+orange peel extract; MCLR+OPE): These rats were given daily microcystin $(10 \mu \mathrm{g} / \mathrm{kg}$ body $\mathrm{wt})$ and orange peel extract $(200 \mathrm{mg} / \mathrm{kg}$ body wt) simultaneously.

Group E (Orange peel extract; OPE): Rats received daily orange peel extract (200 $\mathrm{mg} / \mathrm{kg}$ body wt).

Group F (Jamun seed extract; JSE): Rats received daily jamun seed extract (200 $\mathrm{mg} / \mathrm{kg}$ body wt).

Rats from all the groups (10 from each group) were sacrificed $24 \mathrm{~h}$ after last dose on 15th and 30th day after initiation of the experiment under light ether anesthesia. Animals were fasted overnight before sacrifice.

For use in experiment purified Microcystin LR (Enzo Life Sciences, Inc.) was dissolved in $0.9 \% \mathrm{NaCl}$. The preparation of jamun seed and orange peel extracts have been described in detail by Srivastava et al. (2018).

Kidney of control and treated rats were fixed in Bouin's fluid. These fixed tissues (kidney) were dehydrated in an ethanol gradient, treated with a clearing agent, infiltrated and embedded in paraffin, sectioned at $6 \mu \mathrm{m}$, floated on a heated water bath and mounted to glass slides. After drying overnight, paraffin was removed with a clearing agent, tissue was rehydrated in an ethanol gradient and then stained with hematoxylin and eosin (HE) for light microscopic examination.

For electron microscopic studies, small kidney pieces were fixed in paraformaldehyde and glutaraldehyde mixture for $4 \mathrm{~h}$ at $4{ }^{\circ} \mathrm{C}$, washed with phosphate buffer and stored at $4{ }^{\circ} \mathrm{C}$. These tissues were processed at Sophisticated Analytical Instrument Facility, All India Institute of Medical Sciences, New Delhi, India.

\section{Results}

Kidney of control rats contain numerous nephrons, each nephron consist of a dilated portion, the renal corpuscle; the proximal tubule; loop of Henle and the distal tubule. The renal corpuscles contain a tuft of capillaries, the glomerulus which is surrounded by the Bowman's capsule (Figure 1). There is present the urinary space between the glomerulus and Bowman's capsule. The proximal tubule is lined by simple cuboidal (Figure 2) or columnar epithelium whereas the distal tubule is lined by simple cuboidal epithelium (Figure 1). 


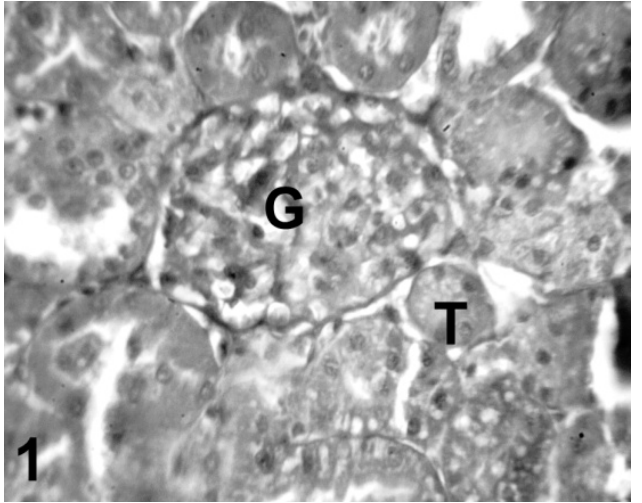

Figure 1. Kidney of control rat showing glomerulus (G) and tubule (T). Hematoxylineosin X 200.

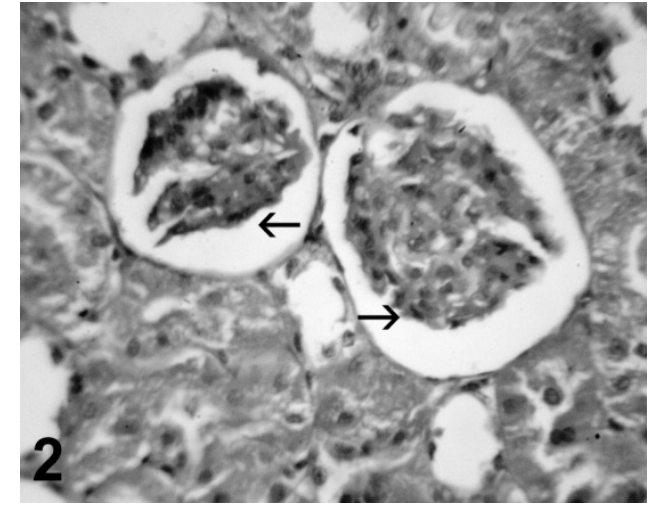

Figure 2. Shrunken glomerulus (arrows) in the kidney of 15 day microcystin treated rat. Hematoxylin-eosin X 200.

In 15 day MCLR treated rats (group B) the glomeruli at few places are noticed to be shrunken thus more space is visible between the Bowman's capsule and glomerulus (Figure 2). The proximal and distal tubules show hypertrophy of epithelial cells, vacuolation of cytoplasm and exhibit obliterated lumina (Figures 3 and 4). In MCLR+JSE (group C) and MCLR+OPE (group D) treated rats almost similar changes are noticed as seen in MCLR treated rats. In OPE (group D) and JSE (group F) treated rats no visible morphological alterations are seen.

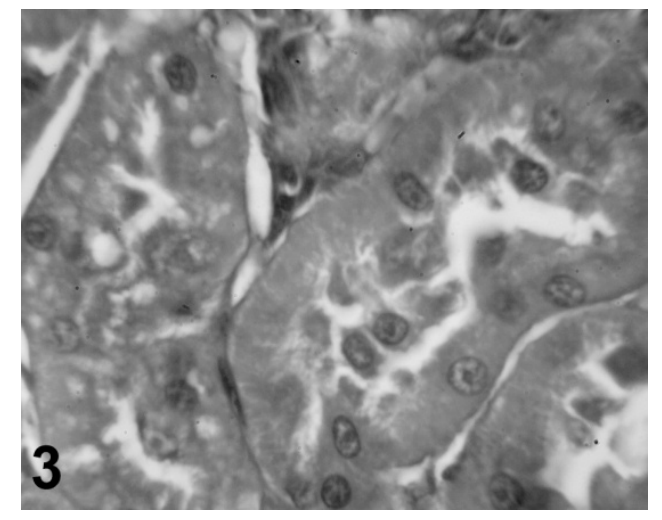

Figure 3. Kidney of 15 day microcystin treated rat showing hypertrophy of tubular epithelium and obliterated lumen. Hematoxylin-eosin X 500 .

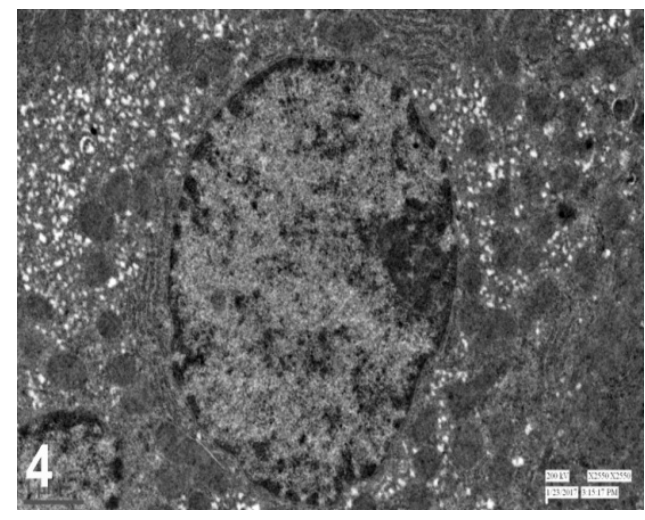

Figure 4. Electron micrograph showing vacuolization in the kidney tubule of 15 day microcystin treated rat.

Following 30 day MCLR treatment (group B), the cellularity of glomeruli is increased at several places thus there is no space between the Bowman's capsule and glomerulus (Figure 5). However, at some places glomeruli are seen degenerating (Figure 6). The proximal and distal tubules are dilated (Figure 7). Tubules also display separation of epithelial cells from underlying basement membrane, vacuolization and degeneration having necrotic nuclei in lumina (Figures 7, 8 and 9). Large deposits of eosinpositive material appear in the tubules (Figures 8 and 10). In MCLR+JSE (group C) and MCLR+OPE (group D) treated rats the glomeruli are swollen showing increased cellularity. No degeneration is noticed in glomeruli. Tubules are dilated, however, at few places few 
epithelial cells are degenerating. Necrotic nuclei are not seen in tubular lumina. In OPE (group E) and JSE (group F) treated rats the kidney architecture is almost similar to control rats.

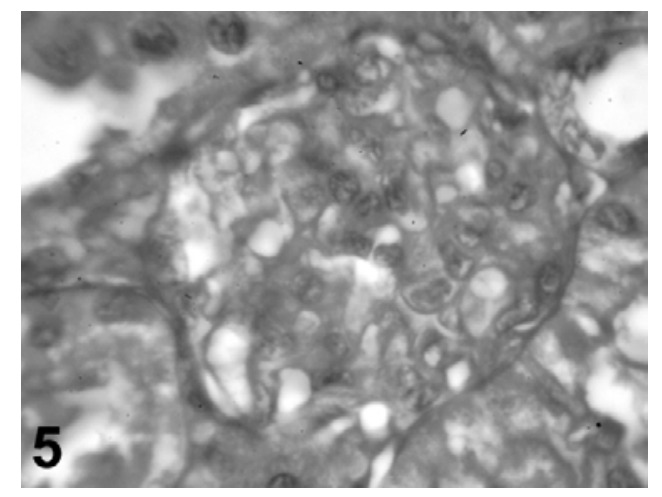

Figure 5. Glomerulus exhibiting hypercellularity after 30 day microcystin treatment. Note the absence of space between the glomerulus and Bowman's capsule. Hematoxylin-eosin X 500.

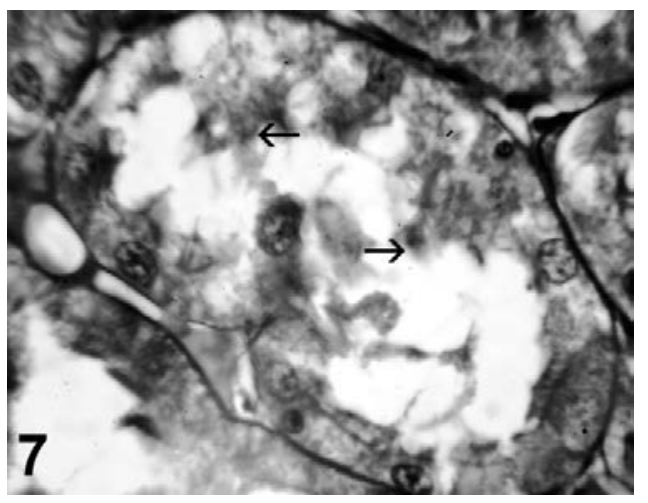

Figure 7. Degeneration (arrows) and dilation of kidney tubules of 30 day microcystin treated rat. Hematoxylin-eosin X 500.

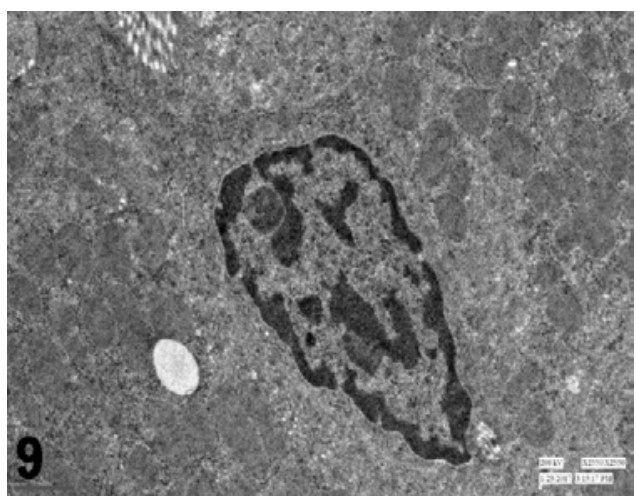

Figure 9. Electron micrograph of kidney of 30 day microcystin exposed rat displaying degeneration of tubular nucleus.

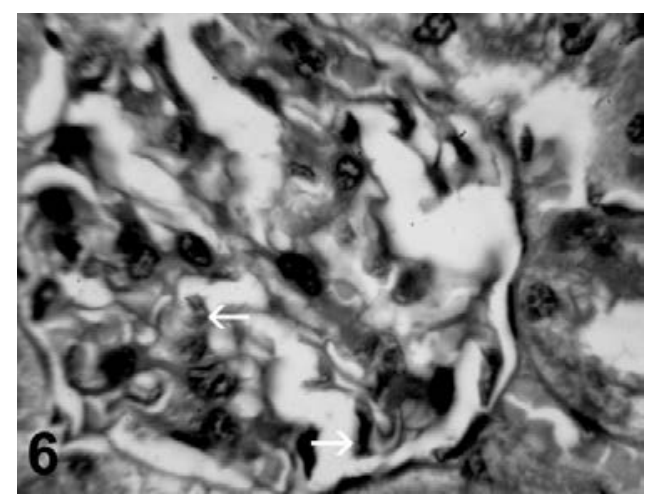

Figure 6. Degeneration of glomerulus (arrows) in 30 day microcystin treated rat. Hematoxylineosin X 500.

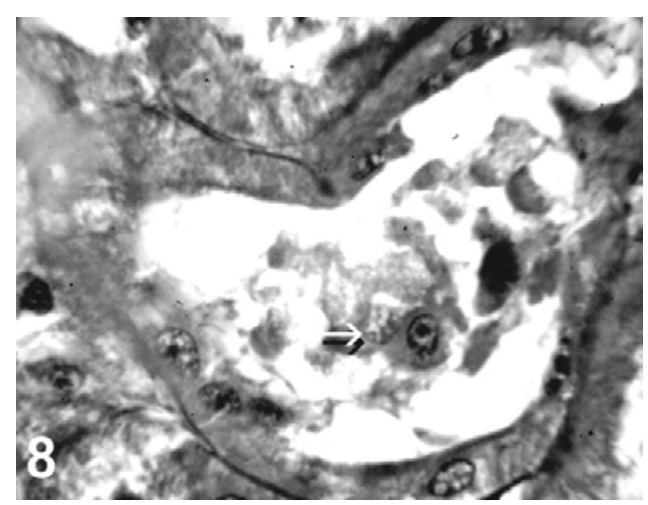

Figure 8. Degenerated tubules displaying necrotic nuclei (arrow) in the lumen of 30 day microcystin exposed rat. Hematoxylin-eosin X 500.

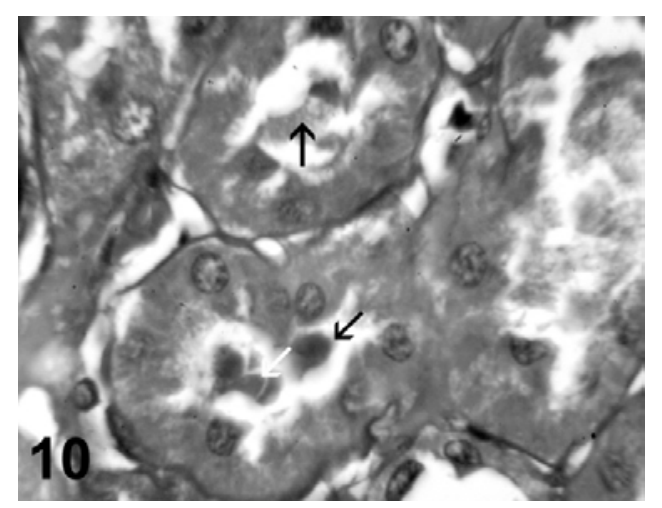

Figure 10. Deposition of eosin-positive substances (arrows) and degenerating nuclei (white arrow) in the tubular lumina of 30 day microcystin treated rat. Hematoxylin-eosin X 500. 


\section{Discussion}

In the present study histological alterations in the kidney has been noticed in MCLR exposed rats. The present study demonstrated glomerular swelling after 30 day in MCLR treated rats. This derives support from studies of other workers who have reported glomerular swelling in kidney of toxicant exposed rat (cadmium - Aughey et al., 1984; Brzoska et al., 2003; Abdel-Moneim and Said, 2007; Tripathi and Srivastav, 2011), rabbit (fluoride - Shashi et al., 2002), quail (lead - Al-Mansour et al., 2009) and mice (MCLR Xiping et al., 2019). Rats treated with MCLR exhibited degeneration of glomeruli and deposition of eosin-positive substances. In past, degeneration of glomeruli has been reported after treatment with microcystin (Atencio et al., 2008; Suput, 2011). Several investigators have noticed toxicant induced glomerular degeneration in vertebrates such as fish - after treatment with chlorpyrifos (Srivastava et al., 1990), deltamethrin (Cengiz, 2006), cadmium (Wangsongsak et al., 2007) and cypermethrin (Korkmaz et al., 2009); chick - after treatment with cypermethrin (Aslam et al., 2009) and rat - after treatment with paraquat (Lamfon and Al-Rawi, 2007), chlorpyrifos (Tripathi and Srivastav, 2010) and cadmium (Tripathi and Srivastav, 2011). Amorphous cellular debris in glomerulus has been noticed in rat exposed to paraquat (Lamfon and Al-Rawi, 2007).

In the foregoing study shrinkage of glomerulus has been observed in MCLR treated rats. Shrinkage of glomerulus concordant with this study has also been reported in rats after exposure to paraquat (Abdel-Mageid, 1994), chlorpyrifos (Tripathi and Srivastav, 2010) and cadmium (Tripathi and Srivastav, 2011). The degeneration of glomerulus in MCLR treated rats may cause decreased GFR as Barrouillet et al. (1999) have noticed decrease in GFR in their in vitro studies of cadmium exposure.

Dilatation of renal tubules have been observed in MCLR exposed rats. This is in agreement with the similar reports by Hooser et al. (1989), Suput (2011) and Xiping et al., (2019), after MCLR treatment. The present study regarding dilatation of kidney tubules derives support from observations on rats (lead - Nunes et al., 2001; cadmium - Kukner et al., 2007, Tripathi and Srivastav, 2011; fenthion - Kerem et al., 2007; fenitrothion - Afshar et al., 2008; endosulfan - Khan and Kumari, 2012; chlorpyrifos - Tripathi and Srivastav, 2010), wood mouse (landfill leachates containing toxic metals - Sanchez-Chardi et al., 2009), rabbit (fluoride - Shashi et al., 2002), quails (lead - Al-Mansour et al., 2009) and fish (chlorpyrifos - Srivastava et al., 1990). Degeneration and vacuolization in the tubular cells have been noticed in MCLR treated rats. This is in concordant with the reports of other investigators who have also noticed similar changes in tubules of microcystin exposed organisms (Hooser et al., 1989; Rabergh et al., 1991; Kotak et al., 1996; Atencio et al., 2008; Suput, 2011; Rangel et al., 2014; Al-Sultan et al., 2015; Al-Majeed et al., 2016). Tubular degeneration has also been reported by other investigators after exposure to various toxicants to vertebrates - fish (chlorpyrifos--Srivastava et al., 1990; cadmium Wangsongsak et al., 2007; cypermethrin - Ayoola and Ajani, 2008); chick (cypermethrin Aslam et al., 2009); quail (lead - Al-Mansour et al., 2009); wood mouse and white-toothed shrew (landfill leachates containing toxic metals - Sanchez-Chardi et al., 2009); monkey (lead - Colle et al., 1980); mice (chlorpyrifos - Thijssen et al., 2007); rabbit (fluoride Shashi et al., 2002); rat (chlorpyrifos - Aughey et al., 1984; Karmakar et al., 1986; Gatta et al., 1989; Brzoska et al., 2003; Abdel-Moneim and Said, 2007; Kukner et al., 2007; Jihen et al., 2008; Tripathi and Srivastav, 2010; metal mixture - Jadhav et al., 2007; paraquat Damain et al., 1992; Abdel-Mageid, 1994; Lamfon and Al-Rawi, 2007; cypermethrin Muthuviveganandavel et al., 2008; fenthion - Kerem et al., 2007; cigarette smoke - Kuru et al., 2009; cadmium - Tripathi and Srivastav, 2011). However, Velisek et al. (2009) have not recorded any change in the kidney of fish treated with bifenthrin.

In MCLR treated rats degenerated cells have been encountered in the tubular lumina. Hosser et al. (1989) and have reported eosinophilic to basophilic material within 
the lumina of renal cortical tubules after MCLR treatment to rats. After microcystin treatment Suput (2011 - in rats) and Xiping et al. (2019 - in mice) have noticed dilated tubules filled with eosinophilic material. Brzoska et al. (2003) and Shashi et al. (2002) have also reported occurrence of degenerated cells in tubular lumina of rats (exposed to cadmium) and rabbit (exposed to fluoride), respectively.

Kidney alterations such as tubular vacuolization, dilatation and degeneration caused by toxicants might be due to hydrolic changes in the renal tissue. These changes clearly indicates that toxicants provoke renal failure in pump transport of tubular cells and also cause functional disturbances in kidney. In past, it has been suggested that dilatation may be a compensatory mechanism after the loss of renal excretory function (SanchezChardi et al., 2009).

\section{Conclusion}

We can conclude that exposure to microcystin adversely affected the kidney structure of the rats. The structural damage caused by microcystin to this vital organ could be protected by supplementation of extracts of jamun seed and orange peel. It is suggested that the microcystin exposed organisms should be given dietary supplement of these botanical extracts which would ease the toxic symptoms.

\section{Acknowledgments}

AKS is thankful to University Grants Commission, New Delhi for providing financial assistance for this study. This work was also partly supported by the cooperative research program of the Institute of Nature and Environmental Technology, Kanazawa University, Japan (Accept No. 20007). The authors are thankful to Sophisticated Analytical Instrument Facility, All India Institute of Medical Sciences, New Delhi, India for processing the tissues for electron microscopy.

\section{Conflict of interest}

The authors declare that they do not have any conflict of interest.

\section{References}

Abdel-Mageid, S. A. Structural changes in the kidney of albino rat in response to the administration of paraquat herbicide. Journal of Basic and Applied Zoology, v. 15, p. 153-175, 1994.

Abdel-Moneim, A. M.; Said, K. M. Acute effect of cadmium treatment on the kidney of rats: Biochemical and ultrastructural studies. Pakistan Journal of Biological Sciences, v. 10, p. 3497-3506, 2007. https://doi.org/10.3923/pjbs.2007.3497.3506

Afshar, S.; Farshid, A. A.; Heidari, R.; Llkhanipour, M. Histopathological changes in the liver and kidney tissues of Wistar albino rat exposed to fenitrothion. Toxicology and Industrial Health, v. 24, p. 581-586, 2008. https://doi.org/10.1177/0748233708100090

Al-Majeed, M. I. A.; Al-Sultan, E. Y. A.; Abbas, A. A. K. Toxic effects of low concentration of cyanotoxin (Microcystin-LR) on mice and study of protective efficacy of the antioxidants vitamins (C\&E) and Capparis spinosa L. root extract. Journal of Natural Sciences Research, v. 6, p. 34-42, 2016. 
Al-Mansour, M. I.; Al-Otaibi, N. M.; Alarifi, S. A.; Ibrahim, S. A.; Jarrar, B. M. Histological and histochemical alterations induced by lead in the kidney of the quail Coturnix coturnix. Toxicological \& Environmental Chemistry, v. 91, no. 6, p. 1191-1203, 2009. https://doi.org/10.1080/02772240802590285

Al-Sultan, E. Y. A.; Al-Majeed, M. I. A.; Abbas, A. A. K. Study of physiological and histological effects under very low concentration of cyanobacterial toxin MC-LR on lab. mice (Mus musculus). Research Journal of Pharmaceutical Biological and Chemical Sciences, v. 6, p. 1064-1072, 2015.

Amorim, A.; Vasconcelos, V. Dynamics of microcystins in the mussel Mytilus galloprovinvialis. Toxicon, v. 37, p. 1041-1052, 1999.

Ashraf, H.; Butt, M. S.; Iqbal, M. J.; Suleria, H. A. R. Citrus peel extract and powder attenuate hypercholesterolemia and hyperglycemia using rodent experimental modeling. Asian Pacific Journal of Troipical Biomedicine, v. 7, p. 870-880, 2017. https://doi.org/ 10.1016/j.apjtb.2017.09.012

Aslam, F.; Khan, A.; Khan, M. Z.; Sharaf, S.; Gul, S. T.; Saleemi, M. K. Toxico-pathological changes induced by cypermethrin in broiler chicks: Their attenuation with vitamin $\mathrm{E}$ and selenium. Experimental and Toxicologic Pathology, v. 62, p.451-450, 2009. https://doi.org/10.1016/j.etp.2009.06.004

Atencio, L.; Moreno, I.; Prieto, A.; Moyano, R.; Molina, A. M.; Camean, A. M. Acute effects of microcystins MCLR and MCRR on acid and alkaline phosphatase activities and pathological changes in intraperitoneally exposed tilapia fish (Oreochromis sp.). Toxicologic Pathology, v. 36, p. 449-458, 2008. https://doi.org/10.1177/0192623308315356

Aughey, E.; Fell, G. S.; Scott, R.; Black, M. Histopathology of early effects of oral cadmium in rat kidney. Environmental Health Perspectives, v. 54, p.153-161, 1984. https://doi.org/10.1289/ehp.8454153

Ayoola, S. O.; Ajani, E. K. Histopathological effects of cypermethrin on juvenile African catfish (Clarias gariepinusi). World Journal of Biological Research, v. 1, p. 1-14, 2008.

Barrouillet, M. P.; Potier, M.; Cambar, J. Cadmium nephrotoxicity assessed in isolated rat glomeruli and cultured mesanglial cells: Evidence for contraction of glomerular cells. Experimental Nephrology, v. 7, p. 251-258, 1999. https://doi.org/10.1159/000020610

Bashandy, S. A. E.; Ahmad-Farid, O. A. H.; Omara, E. A.; El-Toumy, S. A.; Salib, J. Y. Protective effects of Citrus reticulata peel extract against potassium dichromate-induced reproductive toxicity in rats. Asian Pacific Journal of Reproduction, v. 8, p. 267-275, 2019. https://doi.org/10.4103/2305-0500.270104

Bell, S. G.; Codd, G. A. Cyanobacterial toxins and human health. Reviews in Medical Microbiology, v. 5, p. 256-264, 1994.

Benson, J. M.; Hutt, J. A.; Rein, K.; Boggs, S. E.; Barr, E. B.; Fleming, L. E. The toxicity of microcystin LR in mice following 7 days of inhalation exposure. Toxicon, v. 45, p. 691-698, 2005. https://doi.org/10.1016/j.toxicon.2005.01.004

Brózman, O.; Kubickova, B.; Pavel, B.; Petra L. Microcystin-LR does not alter cell survival and intracellular signaling in human bronchial epithelial cells. Toxins, v. 12, no. 3, 165, 2020. https://doi.org/10.3390/toxins12030165

Brzoska, M. M.; Moniuszko-Jakoniuk, J.; Pilat-Marcinkiewicz, B.; Sawicki, B. Liver and kidney function and histology in rats exposed to cadmium and ethanol. Alcohol Alkoholism, v. 38, p. 2-10, 2003. https://doi.org/10.1093/alcalc/agg006 
Calabro, M. L.; Galtieri, V.; Cutroneo, P.; Tommasini, S.; Ficara, R. Study of the extraction procedure by experimental design and validation of a LC method for determination of flavonoids in Citrus bergamia juice. Journal of Pharmaceutical and Biomedical Analysis, v. 35, p. 349-363, 2004.

Carmichael, W. W. Cyanobacteria secondary metabolites: The cyanotoxins. Journal of Applied Bacterialogy, v. 72, p. 445-459, 1992. https://doi.org/10.1111/j.13652672.1992.tb01858.x

Cengiz, E. I. Gill and kidney histopathology in the freshwater fish Cyprinus carpio after acute exposure to deltamethrin. Environmental Toxicology and Pharmacology, v. 22, p. 200-204, 2006. https://doi.org/10.1016/j.etap.2006.03.006

Chagas, V. T.; Coelho, R. M. R. S.; Gaspar, R. S.; Silva, S. A.; Mastrogiovanni, M.; Mendoca, C. J.; Ribeiro, M. N. S.; Paes, A. M. A.; Trostchansky, A. Protective effects of a polyphenol-rich extract from Syzygium cumini (L.) skeels leaf on oxidative stress-induced diabetic rats. Oxidative Medicine and Cellular Longevity, v. 2018, Article ID 5386079, 2018. https://doi.org/10.1155/2018/5386079

Colle, A.; Grimaud, J. A.; Boucherat, M.; Manuel, Y. Lead poisoning in monkeys: Functional and histopathological alterations of the kidneys. Toxicology, v. 18, p. 145-158, 1980. https://doi.org/10.1016/0300-483x(80)90077-3

Damain, F.; Frank, H.; Win Fried, M.; Hartmut, M.; Laus, W. Failure of radiotherapy to resolve fatal lung damage due to paraquat poisoning. Chest, v. 100, p. 1146-1165, 1992.

Dias, E.; Mariana, A.; Elsa, A.; Paulo, P.; Batoreu, M. C. C.; Jordan, P.; Silva, M. J. Comparative study of the cytotoxic effect of microcistin-LR and purified extracts from Microcystis aeruginosa on a kidney cell line. Toxicon, v. 53, p.487-495, 2009. https://doi.org/10.1016/j.toxicon.2009.01.029

Elleman, T. C.; Falconer, I. R.; Jackson, A. R. B.; Runnegar, M. T. Isolation, characterization, and pathology of the toxin from a Microcystis aeruginosa (= Anacystis cyanea) bloom. Australian Journal of Biological Sciences, v. 31, p. 209-218, 1978.

Filipic, M.; Zegura, B.; Sedmak, B.; Horvat-Znidarsic, I.; Milutinovic, A.; Suput, D. Subchronic exposure of rats to sublethal dose of microcystin-YR induces DNA damage in multiple organs. Radiology and Oncology, v. 41, p. 15-22, 2007.

Gatta, A.; Bazzerla, G.; Amodio, P.; Menon, F.; Angeli, P.; Schiaffino, E.; Schmicd, C. Detection of the early steps of cadmium nephropathy: Comparison of light and electronmicroscopical patterns with the urinary enzymes excretion. Nephron, v. 51, p. 20-24, 1989.

Ghasemi, K.; Ghasemi, Y.; Ebrahimzadeh, M. A. Antioxidant activity, phenol and flavonoid contents of 13 citrus species peels and tissues. Pakistan Journal of Pharmaceutical Sciences, v. 22, p. 277-281, 2009.

Gil-Izquierdo, A.; Gil, M.I.; Ferreres, F.; Tomas-Barberan, F. A. In vitro availability of flavonoids and other phenolics in orange juice. Journal of Agricultural and Food Chemistry, v. 49, p. 1035-1041, 2001.

Giri, J.; Sathidevi, T.; Dushyanth, N. Effects of jamun seed extract on alloxan induced diabetes in rats. Journal of the Diabetic Association of India, v. 25, p. 115-119, 1985.

Gorinstein, S.; Martin-Belloso, O.; Park, Y.; Haruenkit, R.; Ciz, M. Comparison of some biochemical characteristics of different citrus fruits. Food Chemistry, v. 74, p. 309-315, 2001. 
Greer, B.; Meneely, J. P.; Elliott, C. T. Uptake and accumulation of Microcystin-LR based on exposure through drinking water: An animal model assessing the human health risk. Scientific Reports, v. 8, 4913, 2018. https://doi.org/10.1038/s41598-018-23312-7

Hegazy, A. E.; Ibrahim, M. I. Antioxidant activities of orange peel extract. World Applied Sciences Journal, v. $18, \quad$ p. 684-688, 2012. https://doi.org/10.5829/ idosi.wasj.2012.18.05.64179

Hooser, S. B.; Beasley, V. R.; Basgall, E. J.; Carmichael, W. W.; Haschek, W. M. MicrocystinLR-induced ultrastructural changes in rats. Veterinary Pathology, v. 27, p. 9-15, 1990. https://doi.org/10.1177/030098589002700102

Hooser, S. B.; Beasley, V. R.; Lovell, R. A.; Carmichael, W. W.; Haschek, W. M. Toxicity of microcystin-LR, a cyclic hepatopeptide hepatotoxin from Microcystis aeruginosa to rats and mice. Veterinary Pathology, v. 26, p.246-252, 1989. https://doi.org/10.1177/ 030098588902600309

Jadhav, S. H.; Sarkar, S. N.; Patil, R. D.; Tripathi, H. C. Effects of subchronic exposure via drinking water to a mixture of eight water-contaminating metals: A biochemical and histopathological study in male rats. Archives of Environmental Contamination and Toxicology, v. 53, p. 667-677, 2007. https://doi.org/10.1007/s00244-007-0031-0

Jihen, H.; Imed, M.; Fatima, H.; Abdelhamid, K. Protective effects of selenium (Se) and zinc ( $\mathrm{Zn}$ ) on cadmium (Cd) toxicity in the liver and kidney of the rat: Histology and Cd accumulation. Food and Chemical Toxicology, v. 46, p. 3522-3527, 2008. https://doi.org/10.1016/j.fct.2008.08.037

Karmakar, N.; Saxena, R.; Anad, R. Histopathological changes in rat tissues by oral intake of lead acetate. Environmental Research, v. 41, p. 23-28, 1986.

Kerem, M.; Bedirli, N.; Gurbuz, N.; Ekinci, O.; Akkaya, T.; Sakrak, O.; Pasaoglu, H. Effects of acute fenthion toxicity on liver and kidney function and histology in rats. Turkish Journal of Medical Sciiences, v. 37, p. 281-288, 2007.

Khan, S.; Kumari, D. Analytical study of histopathological changes induced by endosulfane in kidney of Albino rat. Asian Jornal of Pharmaceutical and Clinical Research, v. 5, p. 113-114, 2012. https://doi.org/10.22270/jddt.v4i3.837

Kim, B.; Cho, J. W.; Kwon, H. N.; Blank, I.; Borisova, I.; Ejaz, S.; Chekarova, I.; Kwon, J.; Lim, C. W. Hepatotoxicity induced by microcystin-LR in rat. Journal of Toxicology and Public Health, v. 22, p. 375-380, 2006.

Korkmaz, N.; Cengiz, E. I.; Unlu, E.; Uysal, E.; Yanar, M. Cypermethrin-induced histopathological and biochemical changes in Nile tilapia (Oreochromis niloticus), and the protective and recuperative effect of ascorbic acid. Environmental Toxicology and Pharmacology, v. 28, p. 198-205, 2009. https://doi.org/10.1016/j.etap.2009.04.004

Kotak, B. J.; Semalulu, S.; Friytz, D. L.; Prepas, E. E.; Hrudey, S. E.; Coppock, R. W. Hepatic and renal pathology of intraperitoneally administered microcystin-LR in rainbow trout (Oncorhynchus mykiss). Toxicon, v. 34, p. 517-525, 1996.

Kukner, A.; Colakoglu, N.; Kara, H.; Oner, H.; Ozogul, C.; Ozan, E. Ultrastructural changes in the kidney of rats with acute exposure to cadmium and effects of exogenous metallothionein. Biological Trace Element Research, v. 119, p. 137-146, 2007. https://doi.org/10.1007/s12011-007-0049-1

Kuru, M.; Ugras, M.; Esrefoglu, M. Effect of resveratrol on tubular damage and interstitial fibrosis in kidneys of rats exposed to cigarette smoke. Toxicology and Industrial Health, v. 25, p. 539-544, 2009. https://doi.org/10.1177/0748233709346755 
Lamfon, H. A.; Al-Rawi, M. M. Effect of antox and paraquat-induced histological and biochemical changes in kidney of albino rats. Journal of Applied Sciences Research, v. 3, p. 988-993, 2007.

Madhuri, S.; Ashwini, U.H.; Srilakshmi, N. S.; Prashith, K. R. Antimicrobial activity of Citrus sinensis and Citrus aurantium peel extracts. Journal of Pharmaceutical and Scientific Innovation, v. 3, p. 366-368, 2014.

Muhtadi, H.; Azizah, T.; Suhendi, A.; Yen, K. H. Antidiabetic and antihypercholesterolemic activities of Citrus sinensis peel: In vivo study. National Journal of Physiology Pharmacy and Pharmacology, v. 5, p. 382-385, 2015. https://doi.org/10.5455/ njppp.2015.5.2807201561

Muthuviveganandavel, V.; Muthuraman, P.; Muthu, S.; Srikumar, K. A study on low dose cypermethrin induced histopathology, lipid peroxidation and marker enzyme changes in male rat. Pesticide Biochemistry and Physiology, v. 91, p. 12-16, 2008. https://doi.org/10.1016/j.pestbp.2007.11.010

Negri, A. P.; Jones, G. J.; Hindmarsh, M. Sheep mortality associated with paralytic shellfish poisoning toxins from the cyanobacterium Anabaena circinalis. Toxicon, v. 33, p. 1321-1329, 1995.

Nunes, J.; Ehrich, M.; Robertson, J. Toxicosis associated with dual oral exposure of rats to lead and trichloroethylene. Toxicologic Pathology, v. 29, p. 451-457, 2001.

Papadimitriou, T.; Kagalou, I.; Stalikas, C.; Pilidis, G.; Leonardos, I. D. Assessment of microcystin distribution and biomagnification in tissues of aquatic food web compartments from a shallow lake and evaluation of potential risks to public health. Ecotoxicology, v. 21, p. 1155-1166, 2012. https://doi.org/10.1007/s10646-012-0870-y

Parashar, S.; Sharma, H.; Garg, M. Antimicrobial and antioxidant activities of fruits and vegetable peels: A review. Journal of Pharmacognosy and Phytochemistry, v. 3, p. 160$164,2014$.

Prakash, C.; Kumar, A.; Prasad, M.; Srivastav, S. K.; Srivastav, A. K. Microcystin-LR attenuates blood calcium and phosphate levels in stinging catfish Heteropneustes fossilis. International Journal of Pharma and Bio Sciences, v. 6, p. 1147-1153, 2015.

Prepas, E. E.; Kotak, B. G.; Campell, L. M.; Evans, J. C.; Hrudey, S. E. Accumulation and elimination of cyanobacterial hepatoxins by the freshwater clam Anodonta grandissimponiana. Canadian Journal of Fisheries and Aquatic Sciences, v. 54, p. 41-46, 1997.

Rabergh, C. M. I.; Bylund, G.; Eriksson, J. E. Histopathological effects of microcystin-LR, acyclic peptide toxin from the cyanobacterium (blue-green alga) Microcystis aeruginosa, on common carp (Cyprinus carpio L.). Aquatic Toxicology, v. 20, p. 131-145, 1991.

Ramful, D.; Bahorum, T.; Bourdom, E.; Tarmus, E.; Aruoma, O. I. Bioactive phenolics and antioxidant propensity of flavedo extracts of Mauritian citrus fruits: Potential prophylactic ingredients for functional foods application. Toxicology, v. 278, p. 75-87, 2010. https://doi.org/10.1016/j.tox.2010.01.012

Rangel, M.; Martins, J. C. G.; Garcia, A. N.; Conserva, A. A.; Costa-Neves, A.; Anna, C. L. S.; Carvalho, L. R. Analysis of the toxicity and histopathology induced by the oral administration of Pseudanabaena galatea and Geitlerinema splendidum (Cyanobacteria) extracts to mice. Marine Drugs, v. 12, p.508-524, 2014. https://doi.org/10.3390/ md12010508 
Raza, A.; Butt, M. S.; Ul-Haq, I.; Suleria, H. A. R. Jamun (Syzygium cumini) seed and fruit extract attenuate hyperglycemia in diabetic rats. Asian Pacific Journal of Tropical Biomedicine, v. 7, p. 750-754, 2017. https://doi.org/10.1016/j.apjtb.2017.07.006

Sanchez-Chardi, A.; Penarroja-Matutano, C.; Borras, M.; Nadal, J. Bioaccumulation of metals and effects of a landfill in small mammals. Part III: Structural alterations. Environmental Research, v. 109, p. 960-967, 2009. https://doi.org/10.1016/j.envres.2009.08.004

Shahi, N.; Monalisa, S.; Mallika, S. K.; Sarmaa, D.; Dasa, P. The microcystins-induced DNA damage in the liver and the heart of zebrafish, Danio rerio. Toxicological and Environmental Chemistry, v. 94, p. 340-349, 2012.

Shashi, A.; Singh, J. P.; Thapar, S. P. Toxic effects of fluoride on rabbit kidney. Fluoride, v. 35, p. 38-50, 2002.

Srivastava, B. D.; Srivastav, A. K. Hepatoprotective effects of extracts of Syzygium cumini seeds and Citrus sinensis peels against microcystin LR-induced toxicity in rat. International Journal of Zoological Investigations, v. 3, p. 95-105, 2017.

Srivastava, B. D.; Srivastava, M.; Srivastav, S. K.; Suzuki, N.; Srivastav, A. K. Cypermethrininduced liver histopathology in rat: Protective role of jamun seed and orange peel extracts. Iranian Journal of Toxicology, v. 12, p. 25-30, 2018.

Srivastava, S. K.; Tiwari, P. R.; Srivastav, A. K. Effects of chlorpyrifos on the kidney of freshwater catfish, Heteropneustes fossilis. Bulletin of Environmental Contamination and Toxicology, v. 45, p. 748-751, 1990.

Suput, D. Effects of microcystins, cyanobacterial toxins, on mammalian cells and organs. Acta Chimica Slovenica, v. 58, p. 708-716, 2011.

Swami, S. B.; Thakor, N. S. J.; Patil, M. M.; Haldankar, P. M. Jamun (Syzygium cumini (L.)): A review of its food and medicinal uses. Food and Nutrition Sciences, v. 3, p. 1100-1117, 2012.

Thijssen, S.; Maringwa, J.; Faes, C.; Lambricht, I.; Van Kerkhove, E. Chronic exposure of mice to environmentally relevant, low doses of cadmium leads to early renal damage, not protected by blood or urine cadmium levels. Toxicology, v. 229, p.145-156, 2007. https://doi.org/10.4236/fns.2012.38146

Tripathi, S.; Srivastav, A. K. Cytoarchitectural alterations in kidney of Wistar rat after oral exposure to cadmium chloride. Tissue and Cell, v. 43, p.131-136, 2011. https://doi.org/10.1016/j.tice.2011.01.001

Tripathi, S.; Srivastav, A. K. Nephrotoxicity induced by long-term oral administration of different doses of chlorpyrifos. Toxicology and Industrial Health, v. 26, p. 439-447, 2010. https://doi.org/10.1177/0748233710371110

Velisek, J.; Svobodova, Z.; Piackova, V. Effects of acute exposure to bifenthrin on some haematological, biochemical and histopathological parameters of rainbow trout (Oncorhynchus mykiss). Veterinarni Medicina, v. 54, p. 131-137, 2009. https://doi.org/10.17221/15/2009-VETMED

Wang, Z.; Li, G.; Wu, Q.; Liu, C.; Shen, J.; Yan, W. Microcystin-LR exposure induced nephrotoxicity by triggering apoptosis in female zebrafish. Chemosphere, v. 214, p. 598605, 2019. https://doi.org/10.1016/j.chemosphere.2018.09.103 
Wangsongsak, A.; Utarnpongsa, S.; Kruatrachue, M.; Ponglikitmongkol, M.; Pokethitiyook, P.; Sumranwanich, T. Alterations of organ histopathology and metallothionein mRNA expression in liver barb, Puntius gonionotus during subchronic cadmium exposure. Journal of Environmental Sciences, v. 19, p. 1341-1348, 2007. https://doi.org/10.1016/ S1001-0742(07)60219-8

Watanabe, M. F.; Harada, K. I.; Carichael, W. W.; Fujiki, H. Toxic microcystis. Boca Raton: CRC Press, 1996.

Williams, D. E.; Dawe, S. C.; Kent, M. L.; Andersen, R. J.; Craig, M. Bioaccumulation and clearance of microcystins from salt water mussels, Mytilus edulis, and in vivo evidence for covalently bound microcystins in mussel tissues. Toxicon, v. 35, p. 1617-1625, 1997.

Xie, L.; Xie, P.; Guo, L.; Miyabara, Y.; Park, H. Organ distribution and bioaccumulation of microcystins in freshwater fish and different trophic levels from the eutrophic Lake Chaohu, China. Environmental Toxicology, v. 20, p. 293-300, 2005.

Xiping, Y.; Shuaishuai, X.; Feiyu, H.; Cong, W.; Shuilin, Z.; Hai, F.; Jian, G.; Jihua, C.; Xiangling, F.; Fei, Y. Effects of chronic exposure to microcystin-LR on kidney in mice. International Journal of Environmental Research and Public Health, v. 16, no. 24, 5030, 2019. https://doi.org/10.3390/ijerph16245030

Zhang, D.; Den, X.; Xie, P.; Yang, Q.; Chen, J.; Dai, M. Determination of microcystin-LR and its metabolites in snail (Bellamya aeruginosa), shrimp (Macrobrachium nipponensis) and silver carp (Hypophthalmichthys molitrix) from Lake Taihu, china. Chemosphere, v. 76, p. 974-981, 2009. https://doi.org/10.1016/j.chemosphere.2009.04.034

Zhao, S.; Liu, Y.; Wang, F.; Xu, D.; Xie, P. N-acetylcysteine protects against microcystin-LRinduced endoplasmic reticulum stress and germ cell apoptosis in zebrafish testes.

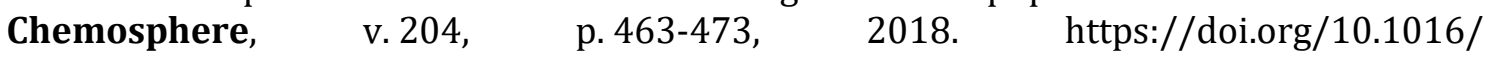
j.chemosphere.2018.04.020

Zin, L. L.; Edwards, W. C. Toxicity of blue-green algae in livestock. Bovine Practioner, v. 14, p. 151-153, 1979. 